\title{
Novel pyridine-based Pd(II)-complex for efficient Suzuki coupling of aryl halides under microwaves irradiation in water
}

\author{
Ismail I. Althagafi ${ }^{1}$, Mohamed R. Shaaban ${ }^{1,2^{*}}$, Aisha Y. Al-dawood ${ }^{1}$ and Ahmad M. Farag ${ }^{2}$
}

\begin{abstract}
Suzuki C-C cross-coupling of aryl halides with aryl boronic acids using new phosphene-free palladium complexes as precatalysts was investigated. A pyridine-based Pd(II)-complex was used in open air under thermal as well as microwave irradiation conditions using water as an eco-friendly green solvent.
\end{abstract}

Keywords: Palladium precatalyst, Suzuki-Miyaura, C-C cross-coupling, Microwave irradiation

\begin{abstract}
Introduction
Palladium is a versatile metal for homogeneous and heterogeneous catalyses [1-4]. Homogeneous palladium catalysis has gained enormous relevance in various coupling reactions, especially in Suzuki reaction. Many products could be synthesized by this methodology for the first time, or in a much more efficient way than before. This kind of catalysis provides high reaction rate and high turnover numbers (TON) and often affords high selectivity and yields [5-7]. Control and use of such Pd catalysts can be tuned by ligands, such as phosphines, amines, carbenes, dibenzylideneacetone (dba), etc. Proper ligand construction has led to catalysts that tolerate weak leaving group such as chloride, exhibit higher TON and reaction rates, improved lifetimes, and are stable to run the reactions without the exclusion of water or air and at lower temperatures $[8,9]$. Recently, there has been considerable interest in the designing of novel phosphorusfree palladium catalysts for higher activity, stability and substrate tolerance that allow reactions to be carried out under milder reaction conditions $[10,11]$. Formamidines are of high interest in synthetic chemistry $[12,13]$ and have been used extensively as pesticides [14-18] and as pharmacological agents [19-21]. They are versatile
\end{abstract}

\footnotetext{
*Correspondence: mrgenidi@uqu.edu.sa

${ }^{1}$ Department of Chemistry, Faculty of Applied Science, Umm Al-Qura

University, Makkah Almukaramah, Mecca, Saudi Arabia

Full list of author information is available at the end of the article
}

ligands, capable of forming flexible coordination modes which lead to various molecular arrangements [22, 23]. Transition metal complexes of formamidinates display novel electronic properties and recently show an extraordinary ability to stabilize high oxidation states [24-30]. On the other hand, reactions that can proceed well in water, which has been reported to be a powerful green solvent, because of its safe and environmentally benign properties [31]. Also, microwave irradiation methodology received a growing interest as a heating source, because of its achievements in green organic synthesis [32-34]. In continuation of our research work concerned with the use of $\mathrm{Pd}(\mathrm{II})$-complexes in $\mathrm{C}-\mathrm{C}$ cross coupling reactions in water, under thermal heating as well as microwave irradiation conditions, $[35,36]$ we report here our study on the catalytic activity of the hitherto unreported, easily accessible $N, N$-dimethyl- $N$ '-pyridyl formamidine-based $\mathrm{Pd}(\mathrm{II})$-complex 4 (catalyst 4) (Fig. 1) as a precatalyst in the Suzuki cross-coupling of aryl halides with a variety of arylboronic acids, in water, under thermal heating as well as microwave irradiation conditions.

\section{Results and discussion \\ Preparation of the Pd(II)-complex 4 (catalyst 4)}

2-Aminopyridine (1) was treated with dimethylformamide dimethyl acetal (2), in benzene, to afford the formamidine derivative 3 as shown in Scheme 1. The $\mathrm{Pd}(\mathrm{II})$-complex 4 was prepared by dissolving the formamidine derivative 3 in methanol followed by addition of 
<smiles></smiles>

Catalyst 4 (complex 4)

Fig. 1 Pyridylformamidine-based $\mathrm{Pd}(\mathrm{II})$-complexe 4 (catalyst 4)

an equimolar amount of sodium tetrachloropalladate, in methanol, at room temperature (Scheme 1). The structure of complex 4 was established based on its elemental analyses and spectroscopic data. The ${ }^{1} \mathrm{H}$ NMR spectrum of the complex 4 showed a singlet signal at $\delta 3.56$ due to $N, N$-dimethylamino protons, in addition to a multiplet at $\delta 6.53-6.55$, two doublet signals in the region at $\delta 7.26-7.48$ due to pyridine ring protons and a singlet at 8.35 due to the formamidine proton. The chemical shift of the protons of the two methyl groups of $\mathrm{N}, \mathrm{N}$-dimethylamino group indicates the effect of the coordination of the nitrogen atom of the $\mathrm{N}, \mathrm{N}$-dimethylamino group with the Pd metal. Comparison of the chemical shift of the same protons in the metal free ligand showed that the resonance of the protons at more down field of the spectrum due to the strong electropositive nature of the metal ion. The IR spectrum of the complex 4 showed a characteristic band at $1629 \mathrm{~cm}^{-1}$ due to the $\mathrm{C}=\mathrm{N}$ function and a band at $771 \mathrm{~cm}^{-1}$ due to the $\mathrm{Pd}-\mathrm{N}$ bond vibration.

\section{Suzuki cross-coupling reactions of aryl bromides}

Factors affecting the optimization of the catalytic activity of complex 4 in Suzuki cross-coupling reactions are given in the following sections.

\section{Effect of concentration of the catalyst 4 on the coupling of $p$-bromoacetophenone with phenylboronic acid in water}

Effect of concentration of the catalyst 4 on the crosscoupling reaction of phenylboronic acid with $p$-bromoacetophenone, in water using potassium hydroxide and tetrabutylammonium bromide (TBAB) as a co-catalyst at $110^{\circ} \mathrm{C}$ for $2 \mathrm{~h}$, was evaluated as shown in Table 1 and scheme 2. At first, the reaction was conducted using $1 \mathrm{~mol} \%$ of the complex (precatalyst) with a molar ratio of $p$-bromoacetophenone $(\mathbf{5 a}) /$ phenylboronic acid (6a)/TBAB/KOH: $1 / 1.2 / 0.6 / 2$, to give $100 \%$ conversion of 4-acetyl-1,1'-biphenyl (7a) based on GC-analysis. In the second experiment, we used $0.75 \mathrm{~mol} \%$ of the catalyst was used which gave full GC-conversion after $2 \mathrm{~h}$ at $110{ }^{\circ} \mathrm{C}$. The reaction was repeated with different concentrations (mol\%) of the catalyst $\mathbf{4}$ as shown in Table 1. In all cases, full conversion was obtained even in the presence of $0.001 \mathrm{~mol} \%$ of the catalyst 4 . It can be concluded, from the data in Table 1, that the catalyst 4 showed excellent catalytic activity. Interestingly, the starting material was completely recovered unchanged when the reaction was carried out without the catalyst 4 (entry 9, Table 1). The structure of the obtained 4-acetylbiphenyl product was confirmed by elemental analyses as well as spectroscopic data (see "Experimental section").

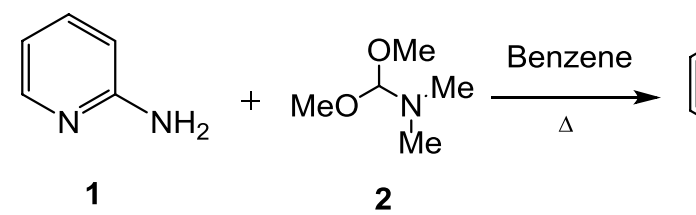

2

3

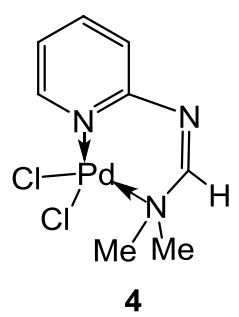

Scheme 1 Preparation of the Pd-complex 4 (catalyst $\mathbf{4}$<smiles>CC(=O)c1ccc(-c2ccccc2)cc1</smiles> 
Table 1 Effect of concentration of catalyst 4 on the coupling of $p$-bromoacetophenone with phenylboronic acid in water under thermal conditions

\begin{tabular}{lll}
\hline Entry & Catalyst $\mathbf{4}$ (mol\%) & GC-yield \% $^{\mathbf{a}, \mathbf{b}}$ \\
\hline 1 & 1 & 100 \\
2 & 0.75 & 100 \\
3 & 0.50 & 100 \\
4 & 0.25 & $100(96)$ \\
5 & 0.125 & 100 \\
6 & 0.05 & 100 \\
7 & 0.025 & 100 \\
8 & 0.005 & 87 \\
9 & 0.00 & 0 \\
\hline
\end{tabular}

a Conditions: $p$-Bromoacetophenone/ phenylboronic acid/TBAB/ base/ water: $1 / 1.2 / 0.6 / 2 / 5 \mathrm{~mL}$, under thermal heating at $100-110^{\circ} \mathrm{C}$ for $2 \mathrm{~h}$

${ }^{\mathrm{b}}$ Conversions were based on $\mathrm{GC}$-analysis and the values between parenthesis refer to the isolated yields

Here, Pd-complexe serve as "dormant species" [37] that is not participate in the real catalytic cycle but considered as a source of a catalytically active species of unknown nature. However, the $\operatorname{Pd}(0)$ species was reported most likely to be the true active catalysts [38]. Therefore, the catalyst $\mathbf{4}$ may serve here as a reservoir that is indirectly involved in the catalytic cycle but is a source of release of a considerable amount of colloidal $\operatorname{Pd}(0)$ which can show catalytic activity at low concentrations.

\section{Effect of solvent and base on Suzuki coupling}

of p-bromoacetophenone (5a) with phenylboronic acid (6a) under thermal conditions

In order to achieve efficient conversions and hence a maximum yield for the cross-coupling reaction, the various parameters and conditions that may affect such cross-coupling were optimized. Solvents and bases are among the most important controlling factors in such optimization. Actually, the selection of a base is still empirical, and no general rule for their choice has been used, therefore, the propriety of some bases and solvents for the coupling reaction between $p$-bromoacetophenone (5a) and phenylboronic acid (6a) were evaluated. As shown in Table 2 and scheme 3, in all cases, the catalyst 4 was used in $0.25 \mathrm{~mol} \%$ concentration and the reaction was carried out thermally in different solvents, e.g. water, DMF, toluene and THF using potassium hydroxide or potassium carbonate as bases. The best result was obtained with water solvent in the presence of tetrabutylammonium bromide (TBAB) or cetyltributylammonium bromide (CTAB) as a co-catalyst after refluxing at $160^{\circ} \mathrm{C}$ (entry 1 and 2, Table 2). The GC-conversion was 100\% and the cross-coupled product 4-acetyl-1,1'-biphenyl (7a) was obtained in 96 and 92\% isolated yield, respectively. Next, water was replaced with DMF, toluene and THF respectively, to give 80,100 and $60 \%$ GC-conversions and in 51, 91 and 50\% isolated yields, respectively. Next, replacement of $\mathrm{KOH}$ with $\mathrm{K}_{2} \mathrm{CO}_{3}$, as a base using water and DMF as solvents was also examined. Again, water proved itself as the good solvent compared with DMF (entry 3 and 5, Table 2).

The choice of solvent is decisive for Pd-catalysts, specifically its complexing properties. Non-aqueous solvents such as DMF can give supernatants which, unlike in cases of aqueous solvents, still show catalytic activity in $\mathrm{C}-\mathrm{C}$ coupling reactions. Therefore, water as an eco-friendly and a green solvent and $\mathrm{KOH}$ as a cheap and common

Table 2 Base and solvent effects on the Suzuki coupling of p-bromoacetophenone (5) with phenylboronic acid (6) under thermal conditions

\begin{tabular}{lllr}
\hline Entry & Base & Solvent & Yield \% ${ }^{\mathbf{a}, \mathbf{b}}$ \\
\hline 1 & $\mathrm{KOH}$ & $\mathrm{H}_{2} \mathrm{O}(\mathrm{TBAB})$ & $100(96)$ \\
2 & $\mathrm{KOH}$ & $\mathrm{H}_{2} \mathrm{O}(\mathrm{CTAB})$ & $100(92)$ \\
3 & $\mathrm{~K}_{2} \mathrm{CO}_{3}$ & $\mathrm{H}_{2} \mathrm{O}(\mathrm{TBAB})$ & $100(94)$ \\
4 & $\mathrm{KOH}$ & $\mathrm{DMF}$ & $80(51)$ \\
5 & $\mathrm{~K}_{2} \mathrm{CO}_{3}$ & $\mathrm{DMF}$ & $80(61)$ \\
6 & $\mathrm{KOH}$ & Toluene & $100(91)$ \\
7 & $\mathrm{KOH}$ & $\mathrm{THF}$ & $60(50)$ \\
\hline
\end{tabular}

a Conditions: $p$-Bromoacetophenone: $1 \mathrm{mmol}$; phenylboronic acid: $1.2 \mathrm{mmol}$; TBAB or CTAB: $0.6 \mathrm{mmol}$; base: $2 \mathrm{mmol}$; solvent: $5 \mathrm{~mL}$, Pd-complex 4: $0.25 \mathrm{~mol} \%$, heating for $2 \mathrm{~h}$ at $160^{\circ} \mathrm{C}\left(\mathrm{H}_{2} \mathrm{O}\right.$ and DMF), $130^{\circ} \mathrm{C}$ (Toluene) and at $90^{\circ} \mathrm{C}$ (THF)

${ }^{\mathrm{b}}$ Conversions were based on $\mathrm{GC}$-analysis and the values between parenthesis refer to the isolated yields<smiles>CC(=O)c1ccc(Br)cc1</smiles>

5a

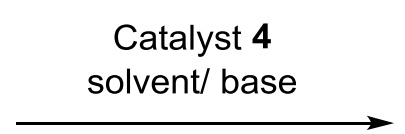

$\Delta$<smiles>CC(=O)c1ccc(-c2ccccc2)cc1</smiles>

$7 a$

Scheme 3 Base and solvent effects on the Suzuki coupling of p-bromoacetophenone (5) with phenylboronic acid (6) 
base are chosen for carrying out all the Suzuki-Miyaura cross-coupling reactions of aryl halides that are used in this work.

\section{Suzuki cross-coupling under microwave irradiation}

The model cross-coupling reaction in water using potassium hydroxide as a base and tetrabutylammonium bromide (TBAB), as a co-catalyst under microwave conditions at $100-160{ }^{\circ} \mathrm{C}$ for $5 \mathrm{~min}$, was achieved as shown in Scheme 4. The reaction was conducted using $1 \mathrm{~mol} \%$ of the catalyst 4 with a molar ratio of 4-bromoacetophenone (5)/phenylboronic acid (6)/TBAB/KOH: 1/1.2/0.6/2 to give $100 \%$ conversion and $96 \%$ isolated yield of 1,1'-biphenyl (5) based on TLC and ${ }^{1} \mathrm{H}$ NMR analysis.

\section{Suzuki coupling of aryl bromides with phenyl boronic acids using catalyst 4 under thermal heating and microwaves irradiation conditions}

Applying the optimized conditions, Suzuki coupling between different aryl bromides $\mathbf{5 b}-\mathbf{g}$ and phenylboronic acid $\mathbf{6 a}$, under thermal heating conditions using the highly active catalyst $\mathbf{4}$, afforded the corresponding biaryls in good yields (Scheme 5). Suzuki-Miyaura reaction of aryl bromides $\mathbf{5 b}-\mathbf{g}$ with the phenylboronic acid $\mathbf{6 a}$ was performed using the catalytic system: water/ $\mathrm{KOH} / \mathrm{TBAB}$, in the presence of $0.25 \mathrm{~mol} \%$ of the catalyst 4. As shown in Table 3. The obtained results reflect the reasonable activity of the catalyst $\mathbf{4}$ towards various aryl bromides $\mathbf{5 b}-\mathbf{g}$.
Table 3 Suzuki coupling of aryl bromides $5 \mathrm{~b}-\mathrm{g}$ with phenylboronic acid using the catalyst 4 under thermal and microwave conditions

\begin{tabular}{lllll}
\hline Entry & $\mathbf{R}$ & Conversion & $\boldsymbol{\Delta}$ yield $\%$ & MW yield \% \\
\hline 1 & $\mathrm{H}$ & 100 & 78 & 92 \\
2 & $2-\mathrm{COCH}_{3}$ & 100 & 61 & 93 \\
3 & $4-\mathrm{OCH}_{3}$ & 100 & 70 & 90 \\
4 & $4-\mathrm{COOH}$ & 100 & 74 & 89 \\
5 & $4-\mathrm{CH}$ & 100 & 24 & 60 \\
6 & $4-\mathrm{OH}$ & 100 & 77 & 87 \\
\hline
\end{tabular}

Conditions: Bromide: $1 \mathrm{mmol}$; phenylboronic acid: $1.2 \mathrm{mmol}$; TBAB: $0.6 \mathrm{mmol}$; $\mathrm{KOH}: 2 \mathrm{mmol}$; water: $5 \mathrm{~mL}$, Pd-complex 4: $0.25 \mathrm{~mol} \%$, microwave heating (300 W) at $110^{\circ} \mathrm{C}$ for $10 \mathrm{~min}$ and thermal heating at $100^{\circ} \mathrm{C}$ for $3 \mathrm{~h}$

\section{Suzuki cross-coupling reactions of other aryl halides}

Next, the cross-coupling reaction between phenylboronic acid (6) and the haloaromatics $8 \mathbf{8}-\mathbf{c}$, in water using potassium hydroxide as a base and tetrabutylammonium bromide (TBAB) as a co-catalyst under thermal conditions at $100{ }^{\circ} \mathrm{C}$ for $1 \mathrm{~h}$, was evaluated as shown in Table 4 and scheme 6 . At first, the reaction was conducted using $1 \mathrm{~mol} \%$ of the catalyst 4 with a molar ratio of haloaromatics (8)/phenylboronic acid (6)/TBAB/KOH: 1/1.2/0.6/2 to give $100 \%$ conversion of $1,1^{\prime}$-biphenyl $(7 \mathbf{b})$ based on TLC and ${ }^{1} \mathrm{H}$ NMR analysis. In all cases, full conversions were obtained as shown in Table 4 , the catalyst 4 is efficient for the cross-coupling of $\mathbf{8}$ with $\mathbf{6}$ at the concentration 1 mol\% catalyst.<smiles>CC(=O)c1ccc(Br)cc1</smiles>

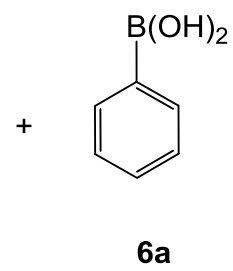

$6 a$<smiles>CC(=O)c1ccc(-c2ccccc2)cc1</smiles>

$7 a$

Scheme 4 Suzuki cross-coupling of p-bromoacetophenone (5) with phenylboronic acid (6) under microwave irradiation<smiles>[R]c1ccc(Br)cc1</smiles>

$5 b-g$<smiles></smiles>

$6 a$

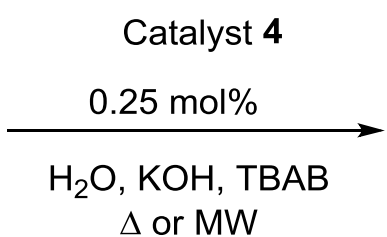

$\triangle$ or MW<smiles>[R]C1CCCCC1</smiles>

7b-g

Scheme 5 Suzuki coupling of aryl bromides $\mathbf{5 b} \mathbf{b} \mathbf{g}$ with phenylboronic acid using the catalyst $\mathbf{4}$ 
<smiles>[X]c1ccc([R])cc1</smiles>

$6 \mathbf{a}$

8a-e

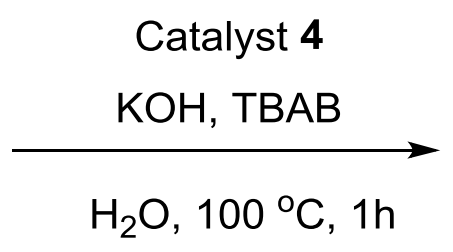

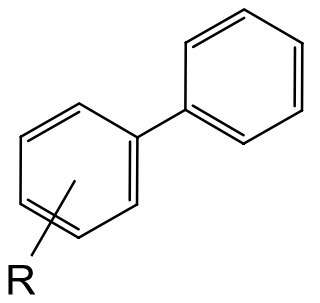

7

Scheme 6 Suzuki coupling of aryl halides $\mathbf{8 a - c}$ with phenylboronic acid

Table 4 Suzuki coupling of aryl halides 8a-c with phenylboronic acid using the catalyst 4 under thermal conditions

\begin{tabular}{lllr}
\hline Entry & $\mathbf{X}$ & $\mathbf{R}$ & Yield \% \\
\hline 1 & $\mathrm{Cl}, \mathbf{b}$ \\
2 & $\mathrm{Cl}$ & $\mathrm{H}$ & $100(90)$ \\
3 & $\mathrm{Cl}$ & $4-\mathrm{OH}$ & $90(82)$ \\
4 & $3-\mathrm{NH}_{2}$ & $85(74)$ \\
5 & $\mathrm{Br}$ & $\mathrm{H}$ & $100(78)$ \\
\hline
\end{tabular}

a Conditions: haloaromatic/ boronic acid/ $\mathrm{KOH} / \mathrm{TBAB} /$ water $(5 \mathrm{~mL}):$ 1/1.2/2/0.6, at $100^{\circ} \mathrm{C}$ for $1 \mathrm{~h}$

${ }^{b}$ Conversions were based on ${ }^{1} \mathrm{H}$ NMR of the crude product and the values between parentheses refer to the isolated yields

\section{Suzuki cross-coupling reactions of halo heteroaromatics}

The thiophene ring is a $\pi$-electron-rich heterocycle and consequently 2-bromothiophene (9) is considered as deactivated bromide in $\mathrm{Pd}$-catalyzed $\mathrm{C}-\mathrm{C}$ coupling reactions. Thus, the cross-coupling reaction between phenylboronic acid (6) and 2-bromothiophene (9), in water using potassium hydroxide as a base and tetrabutylammonium bromide (TBAB) as a co-catalyst, under thermal conditions at $100{ }^{\circ} \mathrm{C}$ for $1 \mathrm{~h}$, was evaluated (Scheme 7). The reaction was conducted using, in each case, $1 \mathrm{~mol} \%$ of the catalyst 4 with a molar ratio of 2-bromothiophene (9)/phenylboronic acid (6)/TBAB/KOH: $1 / 1.2 / 0.6 / 2$. A full conversion of 2-phenylthiophene (10) was observed on the basis of TLC analysis (Scheme 4). Unfortunately, Coupling of 2-bromothiophene with phenylboronic acid in water, under thermal heating, was not efficient where poor yield was obtained and some unidentifiable byproducts were obtained.

\section{Suzuki coupling of p-bromoacetophenone with arylboronic acids using complex 4 under thermal heating as well as microwave irradiation}

The optimized conditions using the highly active catalyst 4 was next applied in the Suzuki coupling between 4-bromoacetophenone (5) and arylboronic acids $\mathbf{6 b - f}$, under thermal heating as well as microwave irradiation conditions (Scheme 8). The Suzuki reaction of 4-bromoacetophenone (5) with the arylboronic acids $\mathbf{6 b}-\mathbf{f}$ was performed using the catalytic system; water/KOH/TBAB in the presence of $0.25 \mathrm{~mol} \%$ of the catalyst 4 (Table 5 ). The obtained results reflect the high activity of the precatalyst 4.

\section{Experimental section Materials and methods}

All melting points were measured on a Gallenkamp melting point apparatus. The infrared spectra were recorded in potassium bromide discs on a Pye Unicam SP 3-300 and Shimadzu FT IR 8101 PC infrared spectrophotometers. The NMR spectra were recorded in deuterated

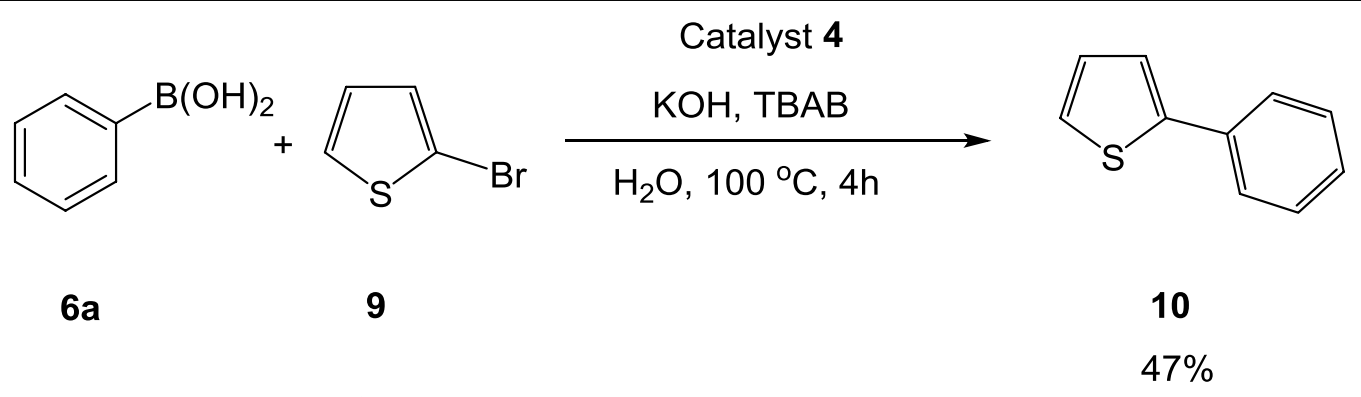

Scheme 7 Suzuki cross-coupling reaction of 2-bromothiophene with phenylboronic acid using catalyst $\mathbf{4}$ under thermal conditions 
chloroform $\left(\mathrm{CDCl}_{3}\right)$ or dimethyl sulfoxide (DMSO- $\left.d_{6}\right)$. On a Varian Mercury VXR-300 NMR spectrometer. Chemical shifts were related to that of the solvent. Mass spectra were recorded on a Shimadzu GCMS-QP1000 EX mass spectrometer at $70 \mathrm{eV}$. Elemental analyses were recorded on a Elementar-Vario EL automatic analyzer at the Micro-analytical Centre of Cairo University, Giza, Egypt. Formamidine 3 is prepared according to our pervious reported work [39] (Scheme 6). The Microwave irradiation was carried out on a CEM mars machine. CEM has several vessel types that are designed for their ovens: Closed-system vessels including the HP-500 (500 psig material design pressure and $260{ }^{\circ} \mathrm{C}$ ), pictured below, have liners are composed of PFA and are ideal for many types of samples. HP-500 Plus vessels are ideal for routine digestion applications. Process up to 14 highpressure vessels per run with temperatures up to $260{ }^{\circ} \mathrm{C}$ or pressures up to $500 \mathrm{psi}$ (Scheme 7).

\section{Synthesis of the Pd(II)-complex (4)}

A solution of sodium tetrachloropalladate $(1 \mathrm{mmol})$, in methanol $(2 \mathrm{~mL})$ was added dropwise to a stirred solution of the formamidine $3(1 \mathrm{mmol})$ in methanol $(10 \mathrm{~mL})$. After stirring for $1 \mathrm{~h}$, the yellow precipitate was filtered off, washed with methanol and dried. The complex 4 was obtained as yellow powder $(70 \%) . \mathrm{mp} 250{ }^{\circ} \mathrm{C} ; 1 \mathrm{H}$ NMR (DMSO- $\left.d_{6}\right) \delta 356\left(\mathrm{~s}, 6 \mathrm{H}, 2 \mathrm{CH}_{3}\right), 6.53-6.55(\mathrm{~m}, 2 \mathrm{H}$, Py-H), 7.25-7.27 (d, 1H, Py-H), 7.46-7.48 (d, 1H, Py-H), 8.35 (s, $1 \mathrm{H}, \mathrm{CH})$; Anal. Calcd for $\mathrm{C}_{16} \mathrm{H}_{14} \mathrm{Cl}_{2} \mathrm{~N}_{2} \mathrm{OPdS}$ : C, 41.80; H, 3.07; N, 6.09. Found: C, 41.68; H, 3.31; N, 6.03.

\section{Suzuki coupling of simple aryl halides}

\section{Effect of concentration of the Pd-complex 4 on the Suzuki} coupling of 4-bromoacetophenone with phenylboronic acid in water under thermal conditions

A mixture of 4-bromoacetophenone (5) (199 mg, $1 \mathrm{mmol})$ and phenylboronic acid (6a) (146 mg, $1.2 \mathrm{mmol})$, tetrabutylammonium bromide (TBAB) (194 $\mathrm{mg}, 0.6 \mathrm{mmol}$ ), Pdcomplex 4 (1 mol\%), $\mathrm{KOH} \mathrm{(112} \mathrm{mg,} 2 \mathrm{mmol}$ ) and water $(10 \mathrm{~mL})$ was stirred at $110^{\circ} \mathrm{C}$ under open air for $2 \mathrm{~h}$ to give 4-acetyl-1,1'-biphenyl (7). The same experiment was
Table 5 Suzuki coupling of p-bromoacetophenone (5) with arylboronic acids using the catalyst 4 under thermal heating and microwave irradiation conditions

\begin{tabular}{lllll}
\hline Entry & $\mathbf{R}$ & Conversion & $\boldsymbol{\Delta}$ yield \% & MW yield \% \\
\hline 1 & $4-\mathrm{CH}_{3}$ & 100 & 90 & 97 \\
2 & $4-\mathrm{Cl}$ & 100 & 93 & 94 \\
3 & $4-\mathrm{F}$ & 100 & 82 & 90 \\
4 & $3-\mathrm{NH}_{2}$ & 100 & 76 & 96 \\
5 & $2,4,6-\left(\mathrm{CH}_{3}\right)_{3}$ & 100 & 83 & 90 \\
\hline
\end{tabular}

Conditions: Bromide: $1 \mathrm{mmol}$; arylboronic acid: $1.2 \mathrm{mmol}$; TBAB: $0.6 \mathrm{mmol}$; $\mathrm{KOH}$ : $2 \mathrm{mmol}$; water: $5 \mathrm{~mL}$, Pd-complex: 4: $0.25 \mathrm{~mol} \%$, microwave heating $(400 \mathrm{~W})$ at $160^{\circ} \mathrm{C}$ and thermal heating at $100^{\circ} \mathrm{C}$

repeated using Pd-complex 4 in 0.75 mol\%. The amount (mol\%) of the Pd-complex 4 was changed with respect to 4-bromoacetophenone $(0.5,0.25,0.125,0.05,0.025$, and $0.005 \mathrm{~mol} \%$ of Pd-complex 4 with scales: 1, 1, 2, 5, 10, and $20 \mathrm{mmol}$ of 4-bromoacetophenone, respectively). The molar ratio of the reaction components were, in all cases, as follows; 4-bromoacetophenone, phenylboronic acid, TBAB, KOH, water: 1/1.2/0.6/2/10 mL water (Scheme 8). The yield\% versus concentration of Pd-complex 4 is outlined in Table 1.

4-Acetyl-1,1'-biphenyl (7a) White solid; mp. 118$120{ }^{\circ} \mathrm{C}$ (lit. mp. $\left.119-120{ }^{\circ} \mathrm{C}\right) ;{ }^{1} \mathrm{H}$ NMR $\left(\mathrm{CDCl}_{3}\right) \delta 2.64$ $\left(\mathrm{s}, 3 \mathrm{H}, \mathrm{CO} \mathrm{CH}_{3}\right), 7.38-7.52(\mathrm{~m}, 3 \mathrm{H}), 7.66-7.70(\mathrm{~d}$, $2 \mathrm{H}, J=6.9 \mathrm{~Hz}), 7.71(\mathrm{~d}, 2 \mathrm{H}, J=7.5 \mathrm{~Hz}), 8.03(\mathrm{~d}, 2 \mathrm{H}$, $J=7.5 \mathrm{~Hz}) ; \mathrm{MS} m / z(\%) 196\left(49.3, \mathrm{M}^{+}\right), 181$ (100), 152 (61.4), 127 (5.2), 76 (9).

\section{Effect of base and solvent on Suzuki cross-coupling of 4-bromoacetophenone with phenylboronic acid under thermal heating}

A mixture of 4-bromoacetophenone (5) (199 mg, $1 \mathrm{mmol}$ ) and phenylboronic acid (6a) (146 mg, $1.2 \mathrm{mmol}$ ), TBAB (194 mg, $0.6 \mathrm{mmol}$ ) (in case of using water as a solvent), Pd-complex 4 (0.25 mol\%), a base $(2 \mathrm{mmol})$ and solvent $(10 \mathrm{~mL})$ was stirred under reflux in open air for $2 \mathrm{~h}$ to give acetyl-1,1'-biphenyl (7). The<smiles>CC(=O)c1ccc(Br)cc1</smiles>

5<smiles>[R]c1ccc(Br)cc1</smiles>

6b-f
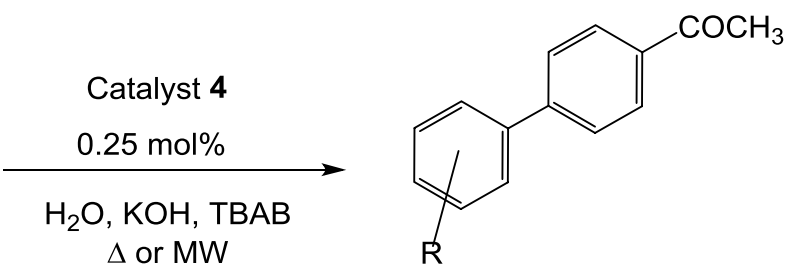

Scheme 8 Suzuki coupling of p-bromoacetophenone $(\mathbf{5})$ with arylboronic acids using the catalyst $\mathbf{4}$ 
molar ratio of the reaction components were, in all cases, as follows; 4-bromoacetophenone, phenylboronic acid, tetrabutylammonium bromide (in case of water), base, solvent: 1/1.2/0.6/2/10 $\mathrm{mL}$. The yield\% versus different solvents and bases is outlined in Table 2 .

\section{Effect of base and solvent on Suzuki cross-coupling of 4-bromoacetophenone with phenylboronic acid under microwave heating}

A mixture of 4-bromoacetophenone (5) (199 mg, $1 \mathrm{mmol}$ ) and phenylboronic acid (6a) (146 mg, $1.2 \mathrm{mmol}$ ), TBAB (194 mg, $0.6 \mathrm{mmol}$ ), Pd-complex 4 (0.25 mol\%), $\mathrm{KOH}(112 \mathrm{mg}, 2 \mathrm{mmol})$ and water $(10 \mathrm{~mL})$ was lunched in the specified CEM reaction vessel HP-500 at a given temperature for $5 \mathrm{~min}$ to give acetyl-1,1'-biphenyl (7).

\section{Suzuki cross-coupling of other aryl halides with phenylboronic acid in water under thermal heating General procedure}

A mixture of the appropriate aryl halides 5 or 8 ( $1 \mathrm{mmol})$, and phenylboronic acid (6a) (146 mg, $1.2 \mathrm{mmol}$ ), tetrabutylammonium bromide (194 $\mathrm{mg}, 0.6 \mathrm{mmol}$ ), Pd-complex 4 (0.25 mol\%), $\mathrm{KOH}$ (112 mg, $2 \mathrm{mmol}$ ), and distilled water (5-10 mL) was stirred at $110{ }^{\circ} \mathrm{C}$ in open air until the reaction was complete (TLC-monitored) as listed in Tables 3 and 4 . The cross-coupled product was then extracted with ethyl acetate $(3 \times 20 \mathrm{~mL})$. The combined organic extracts were dried over anhydrous $\mathrm{MgSO}_{4}$ then filtered and the solvent was evaporated under reduced pressure. The residue was then subjected to separation via flash column chromatography with $n$-hexane/EtOAc (9:1) as an eluent to give the corresponding pure cross-coupled products $\mathbf{7 b}-\mathbf{g}$.

Suzuki cross-coupling of aryl bromides with phenylboronic acid in water under microwave irradiation General procedure

A mixture of the appropriate aryl bromides 5 ( $1 \mathrm{mmol})$, and phenylboronic acid (6a) (146 mg, $1.2 \mathrm{mmol}$ ), tetrabutylammonium bromide (194 mg, $0.6 \mathrm{mmol})$, Pd-complex 4 (0.25 mol\%), $\mathrm{KOH} \mathrm{(112} \mathrm{mg}, 2 \mathrm{mmol})$, and distilled water $(10 \mathrm{~mL})$ were mixed in the specified CEM reaction vessel HP-500. The mixture was heated under microwave irradiating conditions at $110{ }^{\circ} \mathrm{C}$ and 300 Watt for $10 \mathrm{~min}$. After the reaction was complete (monitored by TLC), the reaction mixture was extracted with ethyl acetate $(3 \times 20 \mathrm{~mL})$. The combined organic extracts were dried over anhydrous $\mathrm{MgSO}_{4}$ then filtered and the solvent was evaporated under reduced pressure. The products $\mathbf{7 b}-\mathbf{g}$ were purified by flash column chromatography as described above. The yields\% are outlined in Table 3.

1,1'-Biphenyl (7b) ${ }^{1} \mathrm{H}$ NMR $\left(\mathrm{CDCl}_{3}\right) \delta 7.34-7.40(\mathrm{~m}$, $2 \mathrm{H}), 7.45-7.56(\mathrm{~m}, 6 \mathrm{H}), 8.26(\mathrm{~d}, 2 \mathrm{H}, J=8.1 \mathrm{~Hz}) ; \mathrm{MS} m / z$ (\%) $154\left(36.8, \mathrm{M}^{+}\right), 77$ (100), 50 (42.1).
2-Acetylbiphenyl (7c) ${ }^{1} \mathrm{H}$ NMR (400 MHz, CDCl3) $\delta:$ 7.57-7.49 (m, 4H); 7.45-7.38 (m, 3H); 7.37-7.33 (m, 2H);

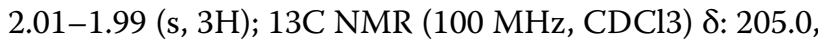
$141.2,140.9,140.8,130.9,130.5,129.1,128.9,128.1$, 127.7, 30.6; MS: $196\left(\mathrm{M}^{+}\right), 181,152$.

4-Methoxy-1,1'-biphenyl (7d) ${ }^{1} \mathrm{H}$ NMR $\left(\mathrm{CDCl}_{3}\right) \delta 3.87$ $\left(\mathrm{s}, 3 \mathrm{H},-\mathrm{OCH}_{3}\right), 6.99$ (d, 2H, $\left.J=8.7 \mathrm{~Hz}\right), 7.31-7.45(\mathrm{~m}$, $3 \mathrm{H}), 7.54(\mathrm{~d}, 2 \mathrm{H}, J=9 \mathrm{~Hz}), 7.57(\mathrm{~d}, 2 \mathrm{H}, J=7.2 \mathrm{~Hz}) ; \mathrm{MS}$ $(m / z)(\%) 184\left(100, \mathrm{M}^{+}\right), 169$ (54.0), 141 (37.4), 115 (16.6), 89 (12.5), 76 (49.8), 63 (25.7).

4-phenylbenzoic acid (7e) ${ }^{1} \mathrm{H}$ NMR (500 MHz, DMSOd6): $\delta(\mathrm{ppm}) 13.17(\mathrm{~s}, 1 \mathrm{H}), 8.03(\mathrm{~d}, \mathrm{~J}=8.5 \mathrm{~Hz}, 2 \mathrm{H})$, $7.79(\mathrm{~d}, \mathrm{~J}=8.0 \mathrm{~Hz}, 2 \mathrm{H}), 7.74(\mathrm{t}, \mathrm{J}=4.2 \mathrm{~Hz}, 2 \mathrm{H}), 7.51$ $(\mathrm{t}, \mathrm{J}=7.5 \mathrm{~Hz}, 2 \mathrm{H}), 7.42(\mathrm{t}, \mathrm{J}=7.2 \mathrm{~Hz}, 1 \mathrm{H}) ; 13 \mathrm{C} \mathrm{NMR}$ (125 MHz, DMSO-d6): $\delta$ (ppm) 167.4, 143.8, 139.1, 130.5, 129.9, 129.0, 128.2, 126.9, 126.6.

4-Methylbiphenyl (7f) ${ }^{1} \mathrm{H}$ NMR (400 MHz, CDCl3)

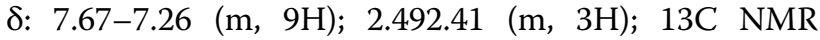
(100 MHz, CDCl3) $\delta: 141.5,138.7,137.3,129.8,129.0$, 127.3, 127.3, 21.4; MS: $168\left(\mathrm{M}^{+}\right), 152$.

4-Hydroxy-1,1'-biphenyl (7g) ${ }^{1} \mathrm{H}$ NMR $\left(\mathrm{CDCl}_{3}\right) \delta 5.05$ (s, 1H, OH), $6.92(\mathrm{~d}, 2 \mathrm{H}, J=7.8 \mathrm{~Hz}), 7.30-7.38(\mathrm{~m}, 1 \mathrm{H})$, 7.40-7.45 (m, 2H), 7.49 (d, 2H, J=8.1 Hz), $7.56(\mathrm{~d}, 2 \mathrm{H}$, $J=8.4 \mathrm{~Hz}) ; \mathrm{MS} \mathrm{m} / \mathrm{z}(\%) 170\left(100, \mathrm{M}^{+}\right), 141$ (32.3), 115 (20.0), 63 (10.3), 51 (12.9).

Suzuki coupling of 2-bromothiophene with phenylboronic acid in water under thermal conditions

A mixture of 2-bromothiophene 9 (1 mmol) and phenylboronic acid (6a) (1.2 mmol), tetrabutylammonium bromide (TBAB) $(194 \mathrm{mg}, 0.6 \mathrm{mmol})$, the Pd-complex 4 (1 mol\%), KOH (112 mg, $2 \mathrm{mmol})$ in water $(10 \mathrm{~mL})$ was stirred at $110{ }^{\circ} \mathrm{C}$ in open air and the reaction was monitored by TLC. After the reaction was completed, the cross-coupling products were then extracted with ethyl acetate $(3 \times 20 \mathrm{~mL})$. The combined organic extracts were dried over anhydrous $\mathrm{MgSO}_{4}$ then filtered and the solvent was evaporated under reduced pressure. The residue was then subjected to a flash column chromatography with $n$-hexane/EtOAc (10:1) as an eluent to give the corresponding pure 2-phenylthiophene $\mathbf{1 0}$.

2-Phenylthiophene (10) ${ }^{1} \mathrm{H}$ NMR $\left(\mathrm{CDCl}_{3}\right) \delta 7.02(\mathrm{~d}, 1 \mathrm{H}$, $J=3.0 \mathrm{~Hz}), 7.06(\mathrm{~d}, 1 \mathrm{H}, J=3.6 \mathrm{~Hz}), 7.08-7.17(\mathrm{~m}, 3 \mathrm{H})$, $7.33-7.40(\mathrm{~m}, 2 \mathrm{H}), 7.49(\mathrm{~d}, 1 \mathrm{H}, J=7.8 \mathrm{~Hz}), 7.59(\mathrm{~d}, 1 \mathrm{H}$, $J=7.8 \mathrm{~Hz}) ; \mathrm{MS} m / z(\%) 160\left(\mathrm{M}^{+}, 100\right), 134$ (33.8), 115 (56.1), 102 (14. 7), 63 (35.5), 45 (56.2).

\section{Suzuki coupling of 4-bromoacetophenone} with arylboronic acids in water under microwave irradiation condition

A mixture of 4-bromoacetophenone (5) $(1 \mathrm{mmol})$ and the appropriate arylboronic acid $6(1.2 \mathrm{mmol})$, tetrabutylammonium bromide (TBAB) (194 $\mathrm{mg}, 0.6 \mathrm{mmol})$, the 
Pd-complex 4 (0.25 mol\%), KOH (112 mg, $2 \mathrm{mmol}$ ) in water $(10 \mathrm{~mL})$ was refluxed (under thermal conditions) or mixed in a process glass vial (under microwave irradiation conditions). After the reaction was complete, the cross-coupled products were then extracted with EtOAc $(3 \times 20 \mathrm{~mL})$. The combined organic extracts were dried over anhydrous $\mathrm{MgSO}_{4}$ then filtered and the solvent was evaporated under reduced pressure. The residue was then subjected to separation via flash column chromatography with $n$-hexane/EtOAc (10:1) as an eluent to give the corresponding pure cross-coupled products $11 \mathbf{a}-\mathbf{e}$ (Table 5 ).

4-Acetyl-4'-Methy-1,1'-biphenyl (11a) ${ }^{1} \mathrm{H} \quad \mathrm{NMR}$ $\left(\mathrm{CDCl}_{3}\right) \delta 2.42\left(\mathrm{~s}, 3 \mathrm{H}, \mathrm{Ar} \mathrm{CH}_{3}\right), 2.64\left(\mathrm{~s}, 3 \mathrm{H}, \mathrm{CO} \mathrm{CH}_{3}\right)$, $7.26(\mathrm{~d}, 2 \mathrm{H}), 7.53(\mathrm{~d}, 2 \mathrm{H}), 7.68$ (d, 2H), 8.03 (d, 2H); MS $m / z(\%) 210\left(70.9, \mathrm{M}^{+}\right)$.

4-Acetyl-4'-Chloro-1,1'-biphenyl (11b) ${ }^{1} \mathrm{H} \quad$ NMR $\left.\left(\mathrm{CDCl}_{3}\right) \delta 2.64(\mathrm{~s}, 3 \mathrm{H}, \mathrm{CO} \mathrm{CH})_{3}\right), 7.33(\mathrm{~d}, 2 \mathrm{H}), 7.63(\mathrm{~d}, 2 \mathrm{H})$, 7.76 (d, 2H), 8.02 (d, 2H); MS $m / z(\%) 230\left(59, \mathrm{M}^{+}\right)$.

4-Acetyl-4'-fluoro-1, 1'-biphenyl (11c) ${ }^{1} \mathrm{H} \mathrm{NMR}\left(\mathrm{CDCl}_{3}\right)$ $\left.\delta 2.64(\mathrm{~s}, 3 \mathrm{H}, \mathrm{CO} \mathrm{CH})_{3}\right), 7.14-7.16(\mathrm{~m}, 2 \mathrm{H}), 7.57-7.65(\mathrm{~m}$, $4 \mathrm{H}), 8.202(\mathrm{~d}, 2 \mathrm{H})$; MS $m / z(\%) 214\left(47, \mathrm{M}^{+}\right)$.

4-Acetyl-3'-amino-1,1'-biphenyl (11d) ${ }^{1} \mathrm{H} \quad$ NMR $\left(\mathrm{CDCl}_{3}\right) \delta 2.63\left(\mathrm{~s}, 3 \mathrm{H}, \mathrm{CO} \mathrm{CH} \mathrm{CH}_{3}\right), 3.74(\mathrm{br}, 2 \mathrm{H}), 6.73(\mathrm{~d}$, $1 \mathrm{H}), 6.93(\mathrm{~s}, 1 \mathrm{H}), 7.00-7.03(1,2 \mathrm{H}), 7.25-7.28(\mathrm{t}, 1 \mathrm{H})$, $7.66(\mathrm{~d}, 2 \mathrm{H}), 8.01(\mathrm{~d}, 2 \mathrm{H}) ; \mathrm{MS} m / z(\%) 211\left(64, \mathrm{M}^{+}\right)$.

4-Acetyl-2', 4', 6'-trimethyl-1, 1'-biphenyl (11e) ${ }^{1} \mathrm{H}$ NMR $\left(\mathrm{CDCl}_{3}\right) \delta 2.01\left(\mathrm{~s}, 6 \mathrm{H}, 2 \mathrm{Ar}-\mathrm{CH}_{3}\right), 2.53\left(\mathrm{~s}, 3 \mathrm{H}, \mathrm{Ar}-\mathrm{CH}_{3}\right)$, $2.66\left(\mathrm{~s}, 3 \mathrm{H}, \mathrm{CO}-\mathrm{CH}_{3}\right), 6.97(\mathrm{~s}, 2 \mathrm{H}), 7.28(\mathrm{~d}, 2 \mathrm{H}), 8.05(\mathrm{~d}$, $2 \mathrm{H}) ; \mathrm{MS} m / z(\%) 238\left(31.6, \mathrm{M}^{+}\right)$.

\section{Conclusions}

In conclusion, we developed a new and an efficient Pdcomplex catalyst for Suzuki $\mathrm{C}-\mathrm{C}$ cross-coupling of aryl halides with aryl boronic acids under green methodology. The activity of the pyridylformamidine based Pd-complex is high even at low mol\% concentrations in the Suzuki cross-coupling between aryl bromides and arylboronic acids in water under microwave irradiation.

\section{Authors' contributions}

MRS designed research and all authors performed research, analyzed the data and wrote the final manuscript with equal contributions. All authors read and approved the final manuscript.

\section{Author details}

${ }^{1}$ Department of Chemistry, Faculty of Applied Science, Umm Al-Qura University, Makkah Almukaramah, Mecca, Saudi Arabia. ${ }^{2}$ Department of Chemistry, Faculty of Science, Cairo University, Giza 12613, Egypt.

\section{Acknowledgements}

The authors are greatly appreciative to Umm Al-Qura University for funding this research (Project No. 43405077).

\section{Competing interests}

The authors declare that they have no competing interests.

\section{Consent for publication}

No consent for publication is needed.
Ethics approval and consent to participate

No ethics approval and consent to participate are needed.

Sample availability

Samples of the compounds are available from the authors.

\section{Publisher's Note}

Springer Nature remains neutral with regard to jurisdictional claims in published maps and institutional affiliations.

Received: 6 April 2017 Accepted: 16 August 2017

Published online: 18 September 2017

\section{References}

1. Alonso F, Beletskaya IP, Yus M (2008) Non-conventional methodologies for transition-metal catalysed carbon-carbon coupling: a critical overview. Part 2: the Suzuki reaction. Tetrahedron 64:3047-3101

2. Nicolaou KC, Bulger PG, Sarlah D (2005) Palladium-catalyzed cross coupling reactions in total synthesis. Angew Chem Int Ed 44:4442-4489

3. Bellina F, Carpita A, Rossi R (2004) Palladium catalysts for the Suzuki cross-coupling reaction: an overview of recent advances. Synthesis 15:2419-2440

4. Miyaura N (2002) Cross-coupling reaction of organoboron compounds via base-assisted transmetalation to palladium(II) complexes. J Organomet Chem 653:54-57

5. Suzuki A (2002) Cross-coupling reactions via organoboranes. J Organomet Chem 653:83-90

6. Suzuki A (2005) Carbon-carbon bonding made easy. Chem Commun 38:4759-4763

7. Miyaura N, Suzuki A (1995) Palladium-catalyzed cross-coupling reactions of organoboron compounds. Chem Rev 95:2457-2483

8. Miura M (2004) Rational ligand design in constructing efficient catalyst systems for Suzuki-Miyaura coupling. Angew Chem Int Ed 43:2201-2203

9. Herrmann WA (2002) N-Heterocyclic carbenes: a new concept in organometallic catalysis. Angew Chem Int Ed 41:1290-1309

10. Zim D, Gruber AS, Ebeling G, Dupont J, Monteiro AL (2000) Sulfur containing palladacycles: efficient phosphine-free catalyst precursors for the Suzuki cross-coupling reaction at room temperature. Org Lett 2:2881-2884

11. Botella L, Najera C (2002) A convenient oxime-carbapalladacycle-catalyzed Suzuki cross-coupling of aryl chlorides in water. Angew Chem Int Ed 41:179-181

12. Meyers Al, Hutchings RH (1993) The asymmetric synthesis of 1-alkyl2,3,4,5-tetrahydro-benzazepines and benzo[3]-1-azabicyclo[1, 3, 5] decanes. Tetrahedron 49:1807-1820

13. Meyers Al, Elworthy TR (1992) Chiral formamidines. The total asymmetric synthesis of (-)-8-azaestrone and related (-)-8-aza-12-oxo-17-desoxoestrone. J Org Chem 57:4732-4780

14. Leung VKS, Chan TYK, Yeung VTF (1999) Amitraz poisoning in humans. Clin Toxicol 37:513-514

15. Nakayama A, Sukekawa M, Eguchi Y (1997) Stereochemistry and active conformation of a novel insecticide, acetamiprid. Pestic Sci 51:157-164

16. Baxter GD, Barker SC (1999) Isolation of a cDNA for an octopamine-like, G-protein coupled receptor from the cattle tick, Boophilus microplus. Insect Biochem Mol Biol 29:461-467

17. Moss II (1996) Synergism of toxicity of N,N-diethyl-m-toluamide to German cockroaches (Orthoptera: Blattellidae) by hydrolytic enzyme inhibitors. J Econ Entomol 89:1151-1155

18. Beeman RW, Matsumura F (1973) Chlordimeform: a pesticide acting upon amine regulatory mechanisms. Nature 242:273-274

19. Gall M, McCall JM, TenBrink RE, VonVoigtlander PF, Mohrland JS (1988) Arylformamidines with antinociceptive properties. J Med Chem 31:1816-1820

20. Donetti A, Cereda E, Bellora E, Gallazzi A, Bazzano C, Vanoni P, Del Soldato P, Micheletti R, Pagani F, Giachetti A (1984) (Imidazolylphenyl) formamidines. A structurally novel class of potent histamine $\mathrm{H}_{2}$ receptor antagonists. J Med Chem 27:380-386 
21. Scott MK, Jacoby HI, Mills JE, Bonfilio AC, Rasmussen CR (1983) 4-(Diphenylmethyl)-1 (iminomethyl)piperidines as gastric antisecretory agents. J Med Chem 26:535-538

22. Barker J, Kilner M (1994) The coordination chemistry of the amidine ligand. Coord Chem Rev 133:219-300 (and references cited therein)

23. Patai S (1975) The chemistry of amidines and imidates, vol 1. Wiley, New York

24. Clerac R, Cotton FA, Dunbar KR, Murillo CA, Wang X (2001) Dinuclear and heteropolynuclear complexes containing Mo-2(4+) unit. Inorg Chem 40:420-426

25. Cotton FA, Lin C, Murillo CA (2000) Metal-metal versus metal-ligand bonding in dimetal compounds with tridentate ligands. Inorg Chem 39:4574-4578

26. Cotton FA, Daniels LM, Murillo CA, Schooler P (2000) Chromium(II) complexes bearing 2-substituted $N, N^{\prime}$-diarylformamidinate ligands. J Chem Soc Dalton Trans 13:2007-2012

27. Cotton FA, Daniels LM, Murillo CA, Schooler P (2000) Chromium(II) complexes bearing 2,6-substituted $N, N^{\prime}$-diarylformamidinate ligands. J Chem Soc Dalton Trans 13:2001-2005

28. Cotton FA, Daniels LM, Matonic JH, Murillo CA (1997) Highly distorted diiron(ii, ii) complexes containing 4 amidinate ligands - a long and a short metal-metal distance. Inorg Chim Acta 256:277-282

29. Arnold DI, Cotton FA, Matonic JH, Murillo CA (1997) Bis ( $N, N^{\prime}$-diphenylformamidine)silver(i) triflate-a 3-coordinate silver formamidine compound stabilized by intramolecular hydrogen-bonds. Polyhedron 16:1837-1841

30. Mitzi DB, Liang K (1997) Synthesis, resistivity, and thermal properties of the cubic perovskite $\mathrm{NH}_{2} \mathrm{CH}=\mathrm{NH}_{2} \mathrm{Snl}_{3}$ and related systems. J Solid State Chem 134:376-381
31. Li CJ (2005) Organic reactions in aqueous media with a focus on carboncarbon bond formations: a decade update. Chem Rev 105:3095-3165

32. Lidström P, Tierney J, Wathey B, Westman J (2001) Microwave assisted organic synthesis - a review. Tetrahedron 57:9225-9283

33. Kappe CO, Stadler A (2005) Microwave theory, chapter 2. In: Mannhold $\mathrm{R}$, Kubinyi $\mathrm{H}$, Folkers $\mathrm{G}$ Microwaves in organic and medicinal chemistry; Wiley-VCH, Weinhiem

34. Hoz A, Ortiz AD, Moreno A (2005) Microwaves in organic synthesis. Thermal and non-thermal microwave effects. Chem Soc Rev 34:164-178

35. Darweesh AF, Shaaban MR, Farag AF, Metz P, Dawood KM (2010) Facile access to biaryls and 2-acetyl-5-arylbenzofurans via Suzuki coupling in water under thermal and microwave conditions. Synthesis 18:3163-3173

36. Shaaban MR, Darweesh AF, Dawood KM, Farag AF (2010) Mizoroki-Heck cross-couplings of 2-acetyl-5-bromobenzofuran and aryl halides under microwave irradiation. Arkivoc (x) 208-225

37. Farina $V$ (2004) High-turnover palladium catalysts in cross-coupling and heck chemistry: a critical overview. Adv Synth Catal 346:1553-1582

38. Louie J, Hartwig JF (1996) A route to Pd(0) from Pd(II) metallacycles in animation and cross-coupling chemistry. Angew Chem Int Ed Engl 35:2359-2361

39. Shaaban MR (2013) Microwave assisted synthesis of bis and tris( $\omega$ bromoacetophenones): versatile precursors for novel bis(imidazo[1,2-a] pyridines), bis(imidazo[1,2-a]pyrimidines) and their tris-analogs. Chem Cent J 7:105-112

\section{Submit your manuscript to a SpringerOpen ${ }^{\odot}$ journal and benefit from:}

- Convenient online submission

- Rigorous peer review

- Open access: articles freely available online

- High visibility within the field

- Retaining the copyright to your article

Submit your next manuscript at $\boldsymbol{\nabla}$ springeropen.com 